\title{
The personal crisis in the selected hospital and impact to the safety
}

\author{
Eva Hoke ${ }^{1, *}$, Romana Heinzová ${ }^{1}$ and Jiři Konečný ${ }^{1}$ \\ ${ }^{1}$ Tomas Bata University in Zlín, Faculty of Logistics and Crisis Management, Studentské nám. 1532, 68601 Uherské Hradiště, Czech \\ Republic
}

\begin{abstract}
The contribution focuses on the current economic situation, especially on low unemployment, which has an impact on the labor market situation in the Czech Republic. Generally, low unemployment is a positive phenomenon in the economy, but what if unemployment is so low that organizations and businesses cannot find high-quality employees? Today, it is already proven that effective using of human capital within economic operators significantly improves their economic performance and, as far as public sector organizations are concerned, it improves public services. Well educated and motivated employees who are not overloaded can become the "brand" of individual healthcare facilities and a human factor as the source of the wealth and prosperity of state and non-state healthcare facilities. Our attention is therefore focused on selected health care organization, where there has been an acute shortage of medical and non-medical staff. The paper deals with the analysis of low unemployment, which is called the personal capacities crisis, its causes and its consequences as well. How to solve this critical shortage of health care staff? So far, the quality of Czech health care has been very high, but if this situation is maintained, the quality of patient care can be fundamentally endangered. The conclusion of the paper contains suggestions and recommendations on how to make this area more effective.
\end{abstract}

\section{Introduction}

Unemployment is a key macroeconomic variable and is crucial for economic planning. The Great Recession of 2008 and the euro debt crisis have had an important effect on the evolution of unemployment in Europe, although there are large cross-country differences. [1] Unemployment is one of the key indicators of economic achievements, together with other macroeconomic goals such as GDP growth, low inflation and a long-term balanced balance of payments.

This article focuses on a situation where unemployment in the Czech Republic has been at its lowest level in the past 23 years. This fact brings both positives and negatives. J. Keynes [2] mentioned that a country that has an unemployment rate of $4 \%$ or less can be called a country that has reached full employment.

The unemployment rate is defined as the percentage of workers who are unemployed and actively looking for a job.

The current labor market has been characterized in recent years by overcoming supply over demand. If the unemployment rate is low, then more people have the opportunity to gain skills, so aggregate labor productivity grows faster. [3] Why is the unemployment rate too low? There are many reasons and causes of such low unemployment.

The first one is speed economic growth. Human capital plays a central role in theories of individual earnings

* Corresponding author: hoke@utb.cz dynamics as well as macroeconomic growth. [3] Recently, we have seen constant economic growth. According to economic experts, the long-term boom or expansion of the Czech economy continues. According to International Monetary Fund is the global economic upswing that began around mid-2016 has become broader and stronger. It is supported by investment, world trade dynamics, favorable financial conditions and expansionary economic policies. [4]

Another important factor that certainly deepens the capacity crisis is the "brain drain" abroad and the aging of the population. With the growing lack of talent, the process of replacing outgoing workers with new employees is becoming increasingly complex. In many fields there is a noticeable lack of professionals who prefer to work abroad. Great problems are solved by both manufacturing plants and healthcare facilities, business firms and service organizations.

Likewise, population aging may cause the shortage of skilled labour which is hard to find. [5]

Demographic development also plays an important role according to the Czech Statistical Office, the population curve culminated in a recession while the "population peak" has already subsided in the last two years.

From the age point of view, the number of inhabitants in the age category 15-64 (it means in the economically active part population) decreased again. The decrease was 0.6 percentage point between 2016 and 2017 and its share now is $65.0 \%$. On the contrary, 
the number of children under the age of 14 and the number of seniors aged 65 and over increased year on year. The share of seniors is in the long term higher (in 2017 it was $19.2 \%$ of persons aged $65+$ ). The aging index is growing steadily and there were 122 seniors per 100 children in 2017. [6]

Another significant influence on the economic recovery and low unemployment was the intervention of the Czech National Bank, ie. artificially weakened crown: thanks to these interventions, foreign companies stayed in the Czech Republic, using relatively cheap and skilled human capital. The weak local currency further reduces the cost of producing goods for export. [7]

We are focused on the health care sector, where the personnel crisis is becoming increasingly serious. There is a shortage of both medical and non-medical staff providing health care for the patient's health in our hospital.

High nursing and doctors turnover and shortages are symptomatic of the problems faced by many hospitals around the world. The nursing shortage crisis is the result of a combination of factors, such as dissatisfaction with current workloads, mandatory shift work, limited career opportunities, perceptions that nurses lack status, tensions in their relationship with other health care professionals, and declining levels of remuneration and job autonomy. [8] Improving the quality of work life of nurses may, therefore, prove to be an effective long-term approach to increasing hospital nurse retention. [9]

\section{Introduction of the selected hospital}

More than 1,700 health service providers and nearly 12,000 health care professionals are involved in the provision of health care in the chosen Region.

The selected Region is the founder of four hospitals in major regional centres. These hospitals are the base of outpatient and inpatient health care for the whole region and health care is provided mainly through regional hospitals. Almost 5,000 employees work in these hospitals, including around 600 doctors and nearly 2,000 nurses and medical assistants. Currently, almost 50 doctors and almost 80 nurses are missing in hospitals. [10]

The Czech Medical Chamber has also issued a statement on the situation in the Czech Republic. According to the Czech Medical Chamber survey, there are missing 826 doctors in regional hospitals, others are missing in Prague. If doctors were to follow the Labor Code exactly, there would be even more. The shortage of workers is linked to a lack of money, presents the Czech Medical Chamber. Thousands of doctors graduate annually at medical faculties, but around 200 of them leave abroad without any work experiences at all in the Czech Republic. The research also suggests that many regional hospitals are devastated by staff and are totally dependent on the work of foreigners. Key departments are closed, such as district offices and pediatrics. [11] It is very important to note that the European Quality Index for Health in Europe in 2015 highlights the Czech Republic, together with Estonia, as countries that offer good health care with low overall health expenditure. Unfortunately, the quality of health care and the high efficiency of Czech health care are achieved at the expense of fair remuneration of health professionals. [11]

This hospital is the largest of the four hospitals set up by the county. Due to the lack of nurses, two beds in the internal intensive care unit are closed, as well as 17 beds in cardiology. There are also 21 nursing beds closed in the hospital for long term illness. However, the hospital's management says that staffing capacity is sufficient. According to the hospital management, nurses and midwives were reduced to 819 last year, 790 last year. [10]

Employers organization of researched hospital threatened to announce the strike alert. The reason for the alert is according to the personal crisis in the hospital and the still unfinished collective agreement for this year. Due to the lack of nurses and auxiliary staff, the department closes, the remaining staff is overloaded with a lot of overtime work and a huge working pace. [10]

\section{Methodology}

We used a method of description in the processing of a literature search concerning the current state of unemployment in the Czech Republic with a focus on the health sector. The most common way of presenting survey data is descriptive statistics method to analyze and synthesize materials, documents and annual reports. The key method for collecting the necessary data for verification and clarification of research questions was a semi-structured interview with the head of the trade union organization of the selected hospital and an analyst at the Health Department of the region under review. The interview was controlled and contained three open questions.

1. What are the causes and main reasons for the lack of medical and non-medical staff?

\section{What is the fluctuation in the selected hospital?}

3. May endanger or. Does the current personal crisis threaten the quality of patient care?

\section{Results}

The results will be presented in this section. The tables below show the development of the number of employees of the hospital in the last four years, divided into specialization and profession. The breakdown is given according to the Czech Health Statistics 2017. The data for processing were drawn from the internal materials of the hospital and based on a semi-structured interview with the staff of the Health Department. [6]

From the table, we can see the rapid fall of employees in the previous year, especially among nurses and midwives, non-medical health professionals under professional supervision and operating workers, workers. For better clarity, we divided the employees of the 
examined hospital into two groups - medical and nonmedical personnel. (Tab. 1 and Tab. 2)

Table 1. Average number of employees - medical personnel.

\begin{tabular}{|c|c|c|c|c|}
\hline $\begin{array}{c}\text { Average } \\
\text { number of } \\
\text { employees }\end{array}$ & $\mathbf{2 0 1 5}$ & $\mathbf{2 0 1 6}$ & $\mathbf{2 0 1 7}$ & $\mathbf{2 0 1 8}$ \\
\hline $\begin{array}{c}\text { Doctors and } \\
\text { dentists }\end{array}$ & 292 & 292 & 305 & 312 \\
\hline Pharmacists & 9 & 9 & 11 & 12 \\
\hline $\begin{array}{c}\text { Nurses, } \\
\text { Midwives }\end{array}$ & 850 & 836 & 819 & 790 \\
\hline $\begin{array}{c}\text { paramedical } \\
\text { workers with } \\
\text { professional } \\
\text { qualifications }\end{array}$ & 137 & 140 & 144 & 219 \\
\hline $\begin{array}{c}\text { paramedical } \\
\text { workers with } \\
\text { professional } \\
\text { and }\end{array}$ & 55 & 57 & 51 & 52 \\
$\begin{array}{c}\text { specialized } \\
\text { qualifications }\end{array}$ & 1725 & 1731 & 1701 & 1618 \\
\hline $\begin{array}{c}\text { health care } \\
\text { workers } \\
\text { pursuing } \\
\text { paramedical } \\
\text { profession } \\
\text { under } \\
\text { professional } \\
\text { supervision }\end{array}$ & 382 & 379 & 371 & 233 \\
\hline \begin{tabular}{c} 
Total \\
\hline $\begin{array}{l}\text { What are the } \\
\text { Paran }\end{array}$
\end{tabular} & & & & \\
\hline
\end{tabular}

What are the causes and main reasons for the lack of medical and non-medical staff? The main reasons for low unemployment and high employment were mentioned above, related to the economic situation of our country. Now, however, we will focus on other reasons that enhance unwanted departures. The chairman of the trade union said that the main reason was the less attractive and prestigious of the profession. The lay public will be impressed by the media that it is a demanding job for little money. Medical school students are already taking the opinion of the demandingness of the profession during their studies and don't want to be employed in a public hospital. They seek employment abroad or private outpatient clinics after graduation. Another reason is mainly related to the demanding nature of the profession and the shift work. While trade unions are trying to fight for salaries and wages in the health sector, we are still lagging behind other professions. The attractiveness of the profession is just the reward that the worker takes away.

We also deliberately mention the number of nonmedical staff as these employees are essential to running the hospital.
Table 2. Average number of employees - non-medical personnel.

\begin{tabular}{|c|c|c|c|c|}
\hline $\begin{array}{c}\text { Average } \\
\text { number of } \\
\text { employees }\end{array}$ & $\mathbf{2 0 1 5}$ & $\mathbf{2 0 1 6}$ & $\mathbf{2 0 1 7}$ & $\mathbf{2 0 1 8}$ \\
\hline $\begin{array}{c}\text { Technical and } \\
\text { economic } \\
\text { personnel }\end{array}$ & 152 & 161 & 171 & 170 \\
\hline $\begin{array}{c}\text { Manual } \\
\text { workers and } \\
\text { operational } \\
\text { personnel }\end{array}$ & 250 & 254 & 257 & 170 \\
\hline Total & 402 & 415 & 428 & 340 \\
\hline
\end{tabular}

From Table 2 we can see that the number of nonmedical staff is also decreasing.

Another important question to the leaders was whether the lower staff level is reflected in lower quality patient care? The trade union chairman declares that the current situation does not correspond to the management's statement. It is proven that some beds are permanently closed, others are temporary. For a long time, one pavilion of the hospital for long term illness has been closed for a long time; only a daycare center has been set up for cardiology for lack of personnel and beds for surgery have been limited. The hospital's management says the hospital's performance has not fallen and that some beds have been closed for a temporary period because they have been replaced by outpatient performance.

So far, we have monitored employment in the selected hospital. Our task is now to identify risk groups of employees. (Table 3)

Table 3. Distribution of personnel structure by age and sex.

\begin{tabular}{|c|c|c|c|c|}
\hline & Men & Women & Total & Percentage \\
\hline $\begin{array}{c}\text { Within 20 } \\
\text { years }\end{array}$ & 1 & 3 & 4 & $0 \%$ \\
\hline $21-30$ years & 43 & 344 & 387 & $19 \%$ \\
\hline $31-40$ years & 61 & 436 & 497 & $26 \%$ \\
\hline $41-50$ years & 47 & 470 & 517 & $28 \%$ \\
\hline $51-60$ years & 84 & 365 & 449 & $22 \%$ \\
\hline 61 and more & 17 & 87 & 104 & $5 \%$ \\
\hline Total & 233 & 1725 & 1958 & $100 \%$ \\
\hline
\end{tabular}


The table and graph show the age distribution of the hospital staff structure as at 31 December 2018.

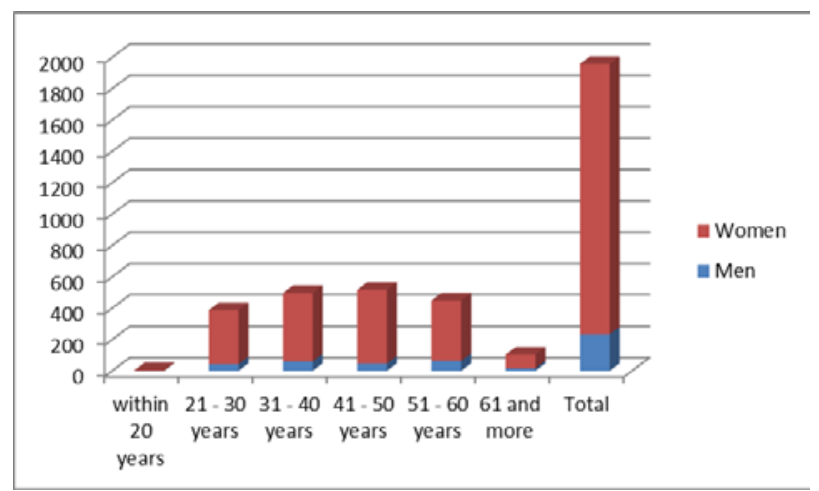

Fig. 1. Distribution of personnel structure by age and sex.

It is clear that $88 \%$ of the employees are women. We consider the number of women in the second and third age groups to be alarming, as these women may leave for maternity leave, possibly at more favourable pay conditions. From the point of view of Human resources management, the current personnel structure is risky, both in terms of the optimal operation of individual departments and in relation to ensuring quality health care for citizens in the selected region.

\section{Discussion}

Based on the analysis of the data we can say that the situation in the selected hospital is really getting worse. This is evidenced by the decreasing number of employees, the closing of beds, the dominance of women and also the slow growth of wages. It is necessary to take up following measures to improve the current situation.

In view of the increasing lack of medical staff throughout the Czech Republic, it is necessary to actively engage in recruitment and, above all, to stabilize current staff. Promoting the hospital, healthcare and increasing the prestige of this job shout be a main task. This is related to strengthening employee benefits for employees.

Another important measure is close cooperation between health schools and hospitals. The lack of doctors of various specialties, but also of non-medical healthcare staff, should be solved by the relevant county, what is the founder of the hospitals. The region, together with hospitals, have payed from September 2016 a scholarship to those students who decide to work in one of the regional hospitals. The scholarship program represents approximately CZK 25,000 for nurses and CZK 50,000 for doctors for the last year of study. Half of the hospital will be involved and half will be the region.

Another option is to accept the Ukraine project. The main goal of the Ukraine project is to help Czech nurses from being overloaded from work, which they do for their own number of missing colleagues. The Ministry of Health has not yet registered any negative responses to the project on nurses. On the contrary, there are still other hospitals, including faculties, who are asking for general and practical nurses. The hospital praises the project and organizes adaptation programs and Czech courses for newcomers from abroad. The Ministry of Health considers the Project Ukraine to be one of the ways to tackle the lack of nurses in our country, and given the positive responses of hospitals.

\section{Conclusion}

The main aim of the contribution was to acquaint the reader with the capacity crisis in the selected hospital, which we can currently observe. The causes of low unemployment were described at the beginning of the article. Our attention was focused on the health sector, where we chose the hospital to analyze the employment status with identifying risk groups. The conclusion of the article belongs to possible refinements and recommendations that could make the situation more effective.

This research was supported by support research program of Tomas Bata University in Zlín (RVO).

\section{References}

1. O. Claveria, J. Labour Market Res, 53, 1 (2019)

2. J. M. Keynes. The General Theory of Employment, Interest, and Money. (Palgrave Macmillan, London, 1936)

3. R. Doppelt, RED, 31 (2019)

4. International Monetary Fund. World Economic Outlook: Cyclical Upswing, Structural Change. (Washington DC, 2018)

5. B. Simo-kengne, HBE, 34, 1 (2019)

6. Czech Health Statistics 2017. Institute of Health Information and Statistics of the Czech Republic (2018)

7. P. Koci. There are not people! How is the Czech economy blocked by record low unemployment. [Internet], Available from: https://www.irozhlas.cz/ekonomika/analyzanizka-nezamestnanost-ceskoekonomika_1802150700_pek (2018)

8. C. A. Chan, K. McBey, M. Basset, M. O’Donnell, R. Winter. RPHRM, 12, 2 (2004)

9. L. Waters. NM, 34, 5 (2003)

10. Internal materials from interviews

11. CTK. The Medical Chamber wants to guaratee providing of medical care by goverment. [Internet], Available from: http://www.zdravotnickydenik.cz/2016/03/lekar ska-komora-chce-od-vlady-aby-zabranilaohrozeni-poskytovani-pece/ (2016)

12. MZCR. The hospital praises the Ukraine project, it is one of the ways to deal with the lack of nurses. [Internet], Available from: http://www.mzcr.cz/dokumenty/projekt- 
ukrajina-pro-sestry-si-nemocnice-chvalije-tojedna-z-moznostijak-res_15408_3684_1.html (2018) 